\title{
Continuity and Change in Gender Relations within the Contract Labour System in Kavango, Namibia, 1925-1972
}

\section{Kletus Muhena Likuwa}

To cite this article: Kletus Muhena Likuwa (2021) Continuity and Change in Gender Relations within the Contract Labour System in Kavango, Namibia, 1925-1972, Journal of Southern African Studies, 47:1, 79-92, DOI: 10.1080/03057070.2021.1857984

To link to this article: https://doi.org/10.1080/03057070.2021.1857984

曲 Published online: 22 Jan 2021.

Submit your article to this journal $\widetilde{ }$

山 Article views: 48

Q View related articles ¿

View Crossmark data $₫$ 


\title{
Continuity and Change in Gender Relations within the Contract Labour System in Kavango, Namibia, 1925-1972
}

\author{
KLetus Muhena LiKuwa
}

(University of Namibia)

\begin{abstract}
The gendered historical investigation of migrant labour in Namibia (and southern Africa more broadly) has rightly considered the ways in which women left behind in the sending areas were obliged to take on additional agricultural duties in the absence of men. This has been viewed by some scholars as a form of material exploitation of women and a potential subsidy to white employers in these settler colonial spheres. While there is some validity to these claims, the relationship between the sending areas and the work site was not simply a material one, and contract/migrant labour recruiting systems entered spaces with existing gendered cultural repertoires concerning how to deal with absent men. The significance of these cultural frameworks is worthy of additional empirical, comparative and theoretical investigation. Through the use of oral interviews supplemented by archival materials, this article discusses these issues in the context of Kavango, north-eastern Namibia, which, for much of the 20th century, was a major source of contract labourers to the colonial economy in what was then South West Africa. The article argues that colonialism and labour recruiting schemes built upon and transformed existing precolonial cultural frameworks such as 'the people's child', women's observance of taboos and a local conception of 'home'. This article further posits that the maintenance of this migrant labour system was dependent upon its integration into local worldviews.
\end{abstract}

Keywords: women; gender relations; migrant labour; cultural change; Kavango; Namibia

\section{Introduction}

For much of the 20th century, north-eastern Namibia's Kavango region was an important source of migrant labour for what was then called South West Africa. Under the contract labour system, men from Namibia's former Kavango and Ovamboland reserves were recruited for 6-18-month contracts to work on mines and farms and in industries within the settler colonial economy. Between 1925 and 1972, recruiting within Kavango was primarily done through the Northern Labour Organisation (NLO) and its successor, the South West Africa Native Labour Association (SWANLA), before being eventually handed over to the Kavango homeland authorities. ${ }^{1}$

This article examines the effects of this stream of labour migrants - averaging 750 men per year for more than 50 years - upon women left behind in Kavango. Within southern

1 For a detailed, broad examination of contract labour in Kavango, see K. Likuwa, Voices from the Kavango: A Study of the Contract Labour System in Namibia, 1925-1972 (Basel, Basler Afrika Bibliographien, 2020). 
African historiography, there are numerous studies examining the 'suffering of women without men' and the destructive impact of migrant labour upon family life, social networks and social relationships. ${ }^{2}$ Much of these discussions relates to the additional agricultural burden placed upon women in the reserves and later homelands (collectively termed 'sending areas'); after all, the ability of employers to pay migrant workers such low wages was dependent upon women, youths and the elderly taking up this agricultural burden. ${ }^{3}$ While there is a degree of validity to these arguments, the relationship between the sending area and the migrant worker was not just one of economic subsidy and subsistence. Scholars need to consider further the cultural relationship and how the coming of contract labour and colonialism built upon and transformed existing cultural relationships; this was anything but a blank slate. ${ }^{4}$

As a whole, this article considers the ways in which three local Kavango cultural frameworks and concepts were reconfigured and repurposed in the context of contract labour. This article examines (1) 'the people's child' (mona vantu), a term originally applied in pre-colonial contexts to men who left the homestead for a long hunting expedition. It was up to women and those left behind to (2) observe certain cultural taboos, such as refraining from quarrelling and avoiding extramarital sex, in order to protect the well-being of 'the people's child' on the hunt. Failure to do so may endanger him and harm his success. It was also up to 'the people's child' to return successfully back to the homestead: this was not a one-way street. In the years of contract labour, the term 'the people's child' was repurposed to describe migrant labourers working on mines and farms and in towns, and women were expected also to observe taboos for the redefined 'people's child'. Finally, this article examines the complex understanding of (3) 'home' in Kavango culture, and the ways in which 'home' was the site of communal continuity. It was for this reason that men on contract (as 'the people's child') were not mandated to observe taboos while on contract in the so-called Police Zone ${ }^{5}$ (central and southern Namibia), since 'home' was located only in Kavango.

Ultimately, this article makes two central contributions to the study of migrant/contract labour in Namibia and beyond. First, it shows that colonialism and contract labour did not enter Kavango (or any sending area, for that matter) with the capacity to transform social relationships and cultural frameworks fully. Rather, these oppressive systems built upon existing concepts and cultural understandings, enabling the institutionalisation of their economic influences. Second, it shows that the contract labour system in Kavango was dependent upon women maintaining a delicate cultural balance; while additional physical and emotional burdens indeed came with the absence of men, maintaining the welfare of 'the people's child', and the decisions by the community to allow him to leave, depended on women's observance of taboos in the Kavango context of 'home'.

While the National Archives of Namibia - a deeply (ex)colonial institution ${ }^{6}$ - contains copious records about the relationship between women and contract labour in Ovamboland, the same cannot be said for the Kavango region, which clearly was not viewed by the

2 C. Walker, 'Gender and the Development of the Migrant Labour System c.1850-1930', in C. Walker (ed.), Women and Gender in Southern Africa to 1945 (Cape Town, David Philip, 1990), pp. 168-96.

3 H. Wolpe, 'Capitalism and Cheap Labour Power in South Africa: From Segregation to Apartheid', Economy and Society, 1, 4 (1972), pp. 425-56.

4 B. Bozzoli, 'Marxism, Feminism, and South African Studies', Journal of Southern African Studies, 9, 2 (1983), pp. 155-6.

5 The Police Zone refers to the area of white settler colonial investment, including the site of most mines, colonial towns and commercial farming operations. It was divided from the northern reserves/homelands by the so-called 'red line', a veterinary cordon fence. See G. Miescher, Namibia's Red Line: A History of a Veterinary and Settlement Border (New York, Palgrave Macmillan, 2012).

6 E.N. Namhila, "Recordkeeping and Missing "Native Estate" Records in Namibia: An Investigation of Colonial Gaps in a Post-Colonial National Archive' (PhD thesis, University of Tampere, 2015), p. 17. 
colonialists as having the same strategic importance. During the apartheid/homeland years, additional records were produced concerning Kavango, but the Administration for Kavango's records have not yet been sorted, reflecting broader challenges faced by historians of this period. ${ }^{7}$ For this reason, extensive oral history research was undertaken in Kavango with men and women concerning the ways their life experiences and cultural frameworks were shaped by contract labour. ${ }^{8}$ After providing a brief historiographical overview, this article will consider how each of these cultural frameworks was incorporated and transformed by the expansion of contract labour in Namibia, noting particularly how women coped with these difficult and changing circumstances.

The contract labour system is mentioned in many historical studies of Namibia, though it is rarely considered as a central point of examination. ${ }^{9}$ In the historiography of migrant labour in Namibia, Kavango has often been sidelined by the more populous Ovamboland. ${ }^{10}$ When Kavango is mentioned as a source of migrant labourers, it is considered secondary to the broader system. ${ }^{11}$ Namibian historiography has rightly highlighted the importance of the contract labour system in shaping the economic and political lives of men away from the homelands on contract, ${ }^{12}$ but much more attention should be devoted to the experiences of women and youths who remained in Kavango. This article is the first attempt to explore some of the cultural transformations and continuities that the contract labour system wrought in Kavango. ${ }^{13}$

Migrant labour throughout southern Africa affected women's agricultural labour production and reproduction of surplus labour through fertility. ${ }^{14}$ During the pre-colonial period, young men often provided labour services for older men in order to acquire cattle and a wife. With colonialism, demand for African labour led the Administration to compel men to leave their rural homes to work for cash wages. In countries such as South Africa, Lesotho and Botswana, research has highlighted links between contract labour, marriage patterns, colonial influx control measures and how they affected women in urban areas. As Cheryl Walker and others have argued, what allowed colonial authorities to export male labour was the system of homestead production in which women were the primary

7 On the topic of disorganised African archives, see, for example, S. Ally, 'Material Remains: Artifice versus Artefact(s) in the Archive of Bantustan Rule', Journal of Southern African Studies, 41, 5 (2015), pp. $977-85$.

8 All interviews for this article were conducted by the author in 2009 or 2020. Informants were located through canvassing villages in Kavango. Transcripts of the interviews for 2009 and 2020 are in the author's possession.

9 Concerning PhD and book-length studies that consider migrant labour in Namibia, see: P. Hayes, 'A History of the Ovambo of Namibia, c.1880-1935' (PhD thesis, University of Cambridge, 1988); J. Silvester, 'Black Pastoralists, White Farmers: Dynamics of Dispossession and Labour Recruitment in Southern Namibia, 1915-1955' (PhD thesis, University of London, 1993); B. Kangumu, Contesting Caprivi: A History of Colonial Isolation and Regional Nationalism in Namibia (Basel, Basler Afrika Bibliographien, 2011); E.N. Namhila, 'Little Research Value': African Estate Records and Colonial Gaps in a Postcolonial National Archive (Basel, Basler Afrika Bibliographien, 2017).

10 On Ovamboland, see: Hayes, 'A History of the Ovambo'; N. Shiweda, 'Omhedi: Displacement and Legitimacy in Oukwanyama Politics, Namibia, 1915-2010', (PhD thesis, University of the Western Cape, 2011); M. McKittrick, To Dwell Secure: Generation, Christianity, and Colonialism in Ovamboland (Portsmouth, Heinemann, 2002).

11 See A.E. Eckl, 'Konfrontation und Kooperation am Kavango (Nord-Namibia) von 1891 bis 1921', (PhD thesis, Universität zu Köln, 2004), pp. 172-6.

12 SWAPO, To Be Born a Nation: The Liberation Struggle for Namibia (Luanda, SWAPO of Namibia, 1981); J. Ya Otto, Battlefront Namibia: An Autobiography (Westport, Lawrence Hill and Co., 1981).

13 Concerning this kind of analysis as it relates to Ovamboland, see: M. McKittrick, To Dwell Secure: Generation, Christianity, and Colonialism in Ovamboland (Portsmouth, Heinemann, 2002), pp. 226-39; N. Hishongwa, The Contract Labour System and its Effects on Family and Social Life: A Historical Perspective (Windhoek, Gamsberg Macmillan, 1992), pp. 95-108.

14 J. Guy, 'Gender Oppression in Southern Africa's Pre-Capitalist Societies', in Walker (ed.), Women and Gender in Southern Africa to 1945, pp. 33-48. 
producers. ${ }^{15}$ It is this system of homestead production that explains the violent opposition of chiefs and men in general to female migration and to the contempt with which the 'town woman' became widely stereotyped as immoral, irresponsible and shockingly independent. ${ }^{16}$

Although involving a relatively small proportion of women, the movement of African women away from the rural areas in southern Africa took on increasingly significant dimensions in the first decades of the 20th century. Women began moving from the rural areas as soon as the establishment of new economic centres opened up the possibility of making a living. A study on women from the former Bophuthatswana homeland shows that, like men, African women left rural areas in search of the new economic opportunities presented by the expanding urban areas. ${ }^{17}$ Women also ran away or 'escaped' from traditional marriages and unsatisfactory family situations to the mushrooming administrative centres, commercial posts and mission stations. ${ }^{18}$ Non-economic factors in women's mobility from the confinements of home include the spread of Christianity and western education. As the efficacy of internalised social sanctions began to break down, chiefs, fathers and husbands felt compelled to turn to more overt forms of control over women's mobility. ${ }^{19}$ In this process, they frequently turned to colonial administrators for assistance, to form a curious alliance with a unifying presumption of male power over women. ${ }^{20}$ Some of the strategies that were used to prevent female migration involved direct prohibitions on the mobility of women by means of pass laws and restricted access to transport. ${ }^{21}$ Since the availability of male labour to work in the colonial economy depended on the continued viability of homestead production, it became the norm for colonial policy makers to intervene on the side of the chiefs and homestead heads against female migration. Ultimately, both colonialists and African men framed the woman's 'place' as a rural one, where the community would be reproduced.

David Coplan, in the context of Basotho migrants to South African mines and towns, reveals the importance and necessity of examining the cultural production of the migrants and the ways in which it linked the sending area to the work site. Lyrics within Basotho musical production were altered to reflect the changed material conditions that people experienced at the mines and the uncertainty and danger that they faced. ${ }^{22}$ Coplan's work reveals the need to explore not just the material and economic aspects of migrant labour and colonial labour policies but also the life experiences and ways in which contract/migrant labour built upon and transformed existing cultural frames. ${ }^{23}$ His study offers methods to understand the relationship between the sending area and the work site; we must also consider cultural worldviews.

In summary, the women's struggle in southern African societies has been a struggle against male control over women's mobility, productive and reproductive labour, fertility and sexuality. ${ }^{24}$ This study expands on existing knowledge of gender relations during the

15 Walker, 'Gender and the Development of the Migrant Labour System'.

16 Ibid.

17 B. Bozzoli, Women of Phokeng: Consciousness, Life Strategy, and Migrancy in South Africa, 1990-1983 (London, James Currey, 1991).

18 Walker, 'Gender and the Development of the Migrant Labour System'.

19 Ibid.

20 M. Akawa, The Gender Politics of the Namibian Liberation Struggle (Basel, Basel Afrika Bibliographien, 2014).

21 Walker, 'Gender and the Development of the Migrant Labour System'.

22 D. Coplan, In Township Tonight! South Africa's Black City Music and Theatre (Chicago, University of Chicago Press, 2007 [1985]).

23 D. Coplan, In the Time of Cannibals: The Word Music of South Africa's Basotho Migrants (Chicago, University of Chicago Press, 1994).

24 J. Guy, 'Gender Oppression in Southern Africa's Pre-Capitalist Societies', in Walker (ed.), Women and Gender in Southern Africa to 1945, pp. 33-48. 
period of the contract labour system by analysing how men and women in the former Kavango homeland applied cultural concepts such as 'the people's child', the observance of taboos in the context of 'home' and how these concepts and practices were transformed under the economic pressures of colonialism. Furthermore, this study examines how these practices and transformations affected women in terms, for example, of the burdens placed upon them and of strategies to cope with these burdens.

\section{The Contract Labourer as 'the People's Child'}

Contract labourers left Kavango not as individuals but as community members, and community relations did not stop once labourers signed contracts. There were thus family responsibilities to ensure the safety of men who left, as it was believed that the actions of family members at home could affect the safety and fortunes of migrants. A contract labourer was referred to by his family and community as 'the people's child' (mona vantu). The concept of 'the people's child' was used in the Kavango to emphasise the need to look out for a person entrusted to women's care. This takes into consideration the possibility that the relatives of that person could eventually take revenge on the contract labourer's wife for any loss, injuries or death of their relative that they believed resulted from her negligence. Since, in most cases, women stayed at home while men travelled, the term mona vantu was used to refer to a contract labourer. The following shikavedi (Kavango cultural song) for Kavango hunters on a buffalo (nyatji) hunting expedition also highlights this by poignantly describing the unpleasant consequences that awaited a woman who failed to observe taboos for her travelling husband's sake: 'mukadi kashi ndirere, pakufa nimona vantu' ('a woman [wife] who does not observe taboo for my sake, when I die, I am the people's child'). ${ }^{25}$ The praise song suggests that a woman who neglects such obligations during her husband's absence from home will surely 'face the music' from her late husband's family for having caused his death through negligence. ${ }^{26}$

While shikavedi songs originated in the pre-colonial period and often applied to men's hunting parties, they were later repurposed to reflect the dangers of the contract labour system to communities in Kavango. Moreover, while the taboo system was seen and used as a means of social control against women, it was more than just that. This was about community reproduction based on a relationship between the community at 'home' and 'the people's child'. One female interviewee expressed why a woman was expected to observe taboos during a husband's absence from home: '[i]f your husband travels, you [a woman] should not commit adultery, as this could cause "the people's child" [her husband] to get injured or die in the mine'. ${ }^{27}$ The 'people's child', as a two-way relationship meant that women, elders and youths at 'home' in the sending area obeyed and observed cultural taboos to protect and provide good fortune to the migrant, with the expectation that returning men would bring goods and money for the whole community. However, these benefits fell short of the community's expectation in many cases.

Women played a central role in the contract labourer's decision to migrate or settle permanently away from home. One contract labourer, for example, upon hearing that his mother had died, returned to ascertain the truth. After he had learned that the story was indeed true, he informed his father that he no longer had any reason to remain in Kavango.

25 For more on the history of the Kavango hunters, see: M. Fisch, The World of the Traditional Hunters along the Kavango River (Windhoek, Macmillan, 2008); S. Kapirika, Mbeli: dimutango daRugciriku (Windhoek, Gamsberg Macmillan, 1993), p. 198.

26 Taboos were observed by women within the migrant labourer's homestead and extended beyond the sole duties of his wife.

27 Interview with R. Kanguro, Kehemu, 18 January 2020. 
But it was only after the persistent persuasion to stay that he asked his father to find him a wife with characteristics and behaviour like that of his late mother so that, whenever he was crying or looked at her, he would be reminded of his mother and would be comforted. ${ }^{28}$ Veronika Mate Mbandje narrated an event concerning her brother, Evalistus Shishuwo Mbandje:

$\ldots$ he arrived [from contract work] $\ldots$ and he asked: 'my older sisters, was it perhaps me that she [our mother] waited for, so that as soon as I had arrived home then our mother dies or what is the meaning of all of this?' ... Then he said, 'yeah, now that this is the case, I am leaving to the east, I am no longer returning to CDM mines ...' Then we stayed for one year and in the second year we received the bad news that our young brother has been trapped in a mine and has died ... ${ }^{29}$

As this narrative shows, there was a belief in the possibility that an ill fate would befall a contract labourer who left 'home' dispirited. In such cases, the labourer risked dying at his workplace, and it was every family member's responsibility to ensure that men left home with peaceful hearts. Women were subjected to a cleansing process before their husbands' journeys and upon their returns. ${ }^{30}$ The women pounded mahangu cereals and prepared the meals that the contract labourers took on their journey, and women performed rituals and observed taboos at home as moral practices aimed at preventing bad luck befalling absent contract labourers. When labourers returned, it was usually the mothers and wives who arranged the welcoming feast. Wives organised the events to celebrate their personal achievement of their faithfulness and adherence to the traditional taboos, which some believed secured the lives and safe return of 'the people's child' to a woman's 'home'. ${ }^{31}$ A contract labourer returning home was seen as a community success since it reflected the hard work of the labourer on contract and the diligence of the sending community.

\section{A Woman's 'Home'}

In southern Africa, one of the means by which men in a male-dominated society controlled women was by giving them a well-defined but circumscribed position within society, to which some status, honour and respectability were attached. ${ }^{32}$ Women who questioned their position lost their privileges because, having questioned social norms and structures, they were no longer controllable. ${ }^{33}$ In Namibia, there was a curious alliance between chiefs, men and colonialists to frame the rural space in the former homelands of Kavango and Owambo as the women's 'home'. In these northern homelands, the ideal woman was depicted as rural-based, whereas urban and independent-minded women were considered immoral. After all, these women resisted the patriarchal ideologies and control. ${ }^{34}$

Colonial officials regarded the rural home as a woman's place. They controlled women's mobility because they feared that they endangered culture and the supply of male labour. ${ }^{35}$ As was the case among the Basotho, a woman, in order to receive the necessary permission to leave 'home' and travel to urban areas, had to furnish proof that her husband or father had

28 Interview with B.S. Katota, Mabushe, 12 August 2009.

29 Interview with V. Mbandje, Katere, 2008.

30 Interview with R. Kanguro, Kehemu, 18 January 2020.

31 M. Caley, 'A Study of Vakwangali Traditional Clothing for Fashion Creation in Namibia' (MA dissertation, University of Namibia, 2020).

32 E. Brink, 'Man-Made Women: Gender, Class and the Ideology of the Volksmoeder', in Walker (ed.), Women and Gender in Southern Africa to 1945, pp. 273-92.

33 Ibid.

34 Shiweda, 'Omhedi', p. 150.

35 An assertion that the concept 'place' is associated with firmness, the law of the proper and the exact, fixed location is articulated in Shiweda, 'Omhedi', p. 10. 
been a resident continuously employed in town for an extended period and that accommodation was available for her. ${ }^{36}$ The control of women's mobility was based on the implementation of a government notice that banned African women from entering urban areas without a travel pass. ${ }^{37}$ Passes were awarded to women to travel to the south only under exceptional circumstances. ${ }^{38}$ There were administrative and 'tribal' instructions that women were not to leave without permission. Disregarding these instructions resulted in punishment. $^{39}$ Hayes shows that, in former Ovamboland, the Christian missions, the commissioner and the chiefs collaborated to impose controls regarding women's place as located in the rural home. ${ }^{40}$ This collaboration could either prevent female mobility into the Police Zone or aid in women's repatriation to the north via guided escorts. ${ }^{41}$ Women without passes in the Police Zone could face charges and get fined, imprisoned and repatriated. This was the experience of Lucia Helemia, who faced repatriation from Tsumeb to Ovamboland in 1939:

[o]n 11 January 1939, Lucia Helemia was tried by the Magistrate on charge of contravening government notice no. 127 of 1937 framed under the provisions of proclamation no. 34 of 1924, entering urban area without certificate and found guilty and fined 10/- or 10 days in hard labour and ordered to return to Owambo land immediately after the completion of her sentence. She paid her fine of $10 /-{ }^{42}$

This shows the experiences that many African women in urban spaces had to undergo at the hands of the colonials. One native recruiter in 1936 declared what he knew and heard about women's mobility and control: 'I often heard Nakare [Harold Eedes] order that no women were to be taken south and also heard Chief Shampapi give similar orders' ${ }^{43}$ Anyone who helped women to leave the former Ovamboland and Kavango could face punishment. A native recruiter who did not adhere to the order and took Angolan women from the Kavango river area to the south was fined, as the following indicates: 'I was fined five head of cattle by Chief Shampapi because I took two women down to Grootfontein last year [1935]. These women were not in possession of a pass. The two women bothered me so much that I eventually took them down to Grootfontein'. ${ }^{44}$ While there are indications that women from former Kavango and Ovamboland migrated to urban spaces, it was not under any formalised recruiting process. Many women travelled for the purpose of receiving medical help and, in the case of girls, for school. While archival documents indicate that women from the Ovambo area migrated and settled permanently in the Police Zone, it is difficult to find the same evidence for women from the Kavango.

Women viewed the establishment of male compounds at workplaces as a colonial strategy to ensure their exclusion. Gorreti Kaundu, who was born in 1945, explained women's exclusion through the compound setups:

36 Walker, 'Gender and the Development of the Migrant Labour System'.

37 National Archives of Namibia (NAN) NAT 22/31: Magistrate Grootfontein to Officer in Charge of Natives Affairs, Tsumeb 'Influx of Native Women to Tsumeb', 23 August 1937.

38 Shiweda, 'Omhedi'.

39 Ibid.

40 P. Hayes, 'Cocky Hahn and the Black Venus: The Making of a Native Commissioner in South West Africa, 1915-46', Gender and History, 8, 3 (1996), p. 372.

41 NAN NAT 22/31: Native Commissioner, Ovamboland (Hahn) to Magistrate Grootfontein, 'Re: Unemployed Native Women, Tsumeb Urban Area' - 23 March 1937.

42 NAN NAT 22/31: Officer in Charge of Natives Affairs, Tsumeb to Officer in Charge of Native Affairs, Ondangwa, 'Lucia Helemia Charged for Entering Urban Area Without a Certificate' - 12 January 1938.

43 NAN NAR 1/1/55, file 11/1: Langhans Kanyinga, 'Declaration' - 22 January 1936. For more discussions on native recruiters, see K. Likuwa and N. Shiweda, 'Native Recruiters' Activities along the Kavango River Boundary in North-East Namibia, 1925-1943', Journal of Namibian Studies, 23 (2018), pp. 87-100.

44 NAN NAR 1/1/55, file 11/1: Langhans Kanyinga, 'Declaration' - 22 January 1936. 
... they [colonial authorities] did not build houses but only compounds for men. Women were refused permission to travel. Even when one looks at the situation in Namibia, where did they construct houses for women? Only the men lived in single quarters and, as in South Africa, there was no place for a woman in a compound in Namibia. Even if a woman wanted to take along children for a visit, where would they stay? Yes, that is what prevented them $\ldots{ }^{45}$

Women from the former Kavango and Owambo homelands were thus prevented by the colonialists and chiefs from working in public spaces and were instead kept in the former homelands where they produced food for families. ${ }^{46}$ This discourse of 'responsible patriarchy' was shared by both administration and Owambo male elders. ${ }^{47}$ Women were aware that the negative patriarchal and colonial views about women's mobility were based on men's misguided distrust and fear that women would remarry or form liaisons with other men. As one woman remarked: 'will they allow you? Will you [a woman] go alone or will your husband accompany you? Even your husband would say you are lying and that you are only going for men'. ${ }^{48}$

\section{Women's Taboos}

In Kavango, a general rule was that taboos had to be observed by those who stayed at home. Since the traditional economy (hunting and long-distance trading) and, later, the colonial economy (such as the contract labour system) was mainly male-centred, the pressure or burden to observe taboos was placed on women. Taboos practised primarily by women during men's absence were an instrument for men to control women socially. The tabooed acts included, but were not limited to, adultery, fighting and quarrelling. The traditional belief was that such acts committed by a wife placed a travelling husband at the risk of being injured or even killed. This is what shaped community expectations of women to maintain good morals. Maria A. Caley asserts that 'sisindi savanda' (literally, 'a hidden trunk') was a metaphor used among the Vakwangali to refer to a woman who remained faithful during her husband's absence. ${ }^{49}$ It was believed that a woman's faithfulness, or lack thereof, determined whether her husband would encounter misfortune while on contract. Ultimately, taboos and cleansing processes tended to be observed by women partly because of the local understanding that 'home' was the site of cultural continuity; men, away from 'home' on contract, were not subject to these obligations. Bernhard Shampapi explained:

[a] man, while at his contract work destination, did not observe any taboo acts. It is a woman who was left at home in the marital house or room who had to observe the taboo.

She should never bring any bad elements in the house, she should not fight or quarrel with other people because these could cause her husband getting injured at his work place ... ${ }^{50}$

The understanding of 'home' as a historically and geographically rooted identity where the family or community was reproduced meant that only those who remained in Kavango were expected to observe taboos. Men away from 'home' were not mandated in the same way as women who were left at 'home' to uphold marital fidelity standards. Since 'home' was located only in the former Kavango and never at the work destinations, contract

45 Interview with G. Kaundu, Kehemu, 11 February 2020.

46 H. Becker, 'A Concise History of Gender, Tradition and the State in Namibia', in C. Keulder (ed.), State, Society and Democracy: A Reader in Namibian Politics (Windhoek, Konrad Adeneur Stiftung, 2010), pp. $181-2$.

47 Hayes, 'A History of the Owambo of Namibia', p. 288.

48 Interview with A.K. Maliti, Ndiyona, 11 February 2020.

49 Caley, 'A Study of Vakwangali Traditional Clothing'.

50 Ibid. 
labourers believed that their immoral acts (such as adultery or second marriages) while on contract did not violate a taboo. ${ }^{51}$ While men having extramarital sex away from 'home' might have presented a problem for him and his wife, it was not viewed as an existential threat to the welfare of community members. Men's infidelity in the Police Zone was not thought to be a threat to safety in the way that his wife's infidelity at 'home' might be. Furthermore, if men engaged in extramarital sex at 'home' in Kavango, it would be viewed in the same way as a woman's infidelity. It was not the action committed that was at issue but rather where it was happening. The contract labour system thus built upon certain cultural institutions such as 'the people's child' and taboos by incorporating and transforming them, although mostly as a burden on and to the detriment of women.

\section{Burdens upon Women and their Coping Strategies}

In Kavango, women could respond to the added agricultural burden caused by the absence of husbands and sons by calling on ndjambi work parties. Ndjambi was a cultural institution that originated in pre-colonial times and was transformed in the colonial era. It entailed organising community members to plough one's field, after which one invited all the helpers to a beer-drinking feast at one's homestead. Since agricultural output relied on rain, in some cases the produce was small and thus hunger was not uncommon in some families. Women did not regard food as a central benefit or expectation from returning labourers, since they could obtain this through their own agricultural activities. However, they expected various material items that were difficult to obtain locally. Women's sole role in food production when men were absent meant that they could hold their husbands accountable to bring back all of their wages, as well as modern goods. ${ }^{52}$ The oral narratives confirm that women benefited from the acquisition of items such as bundles of loincloths, blankets and cooking utensils. ${ }^{53}$ Further, the acquisition of items such as viranda (necklace) supplemented traditional animal-skin clothing. Women received trade cloth and other European commodities from the returning labourers, which added to their distinct look and image within their communities. ${ }^{54}$ Sometimes they were disappointed when returning contract labourers lacked the cash to fulfil family expectations. ${ }^{55}$

In Kavango, when a man married he usually sent his wife to his parents' or maternal uncle's homestead during his absence under the contract labour system. ${ }^{56}$ A wife under the control of her in-laws risked losing support from her husband's wages once he returned to Kavango if she abandoned her in-laws' homestead. Further, it seems that colonial officials helped women to obtain remittances from migrant husbands or sons only if women adhered to the custom of staying in the in-laws' homestead. ${ }^{57}$ However, even if she lived in her inlaw's homestead for most of her married life, she did not control the distribution of her husband's material items. This right was traditionally reserved for her in-laws. Kanguro poignantly explains a woman's position and further likens a wife's experiences while she was living with her in-laws to those of men under the exploitative contract labour system:

51 Interview with B.L. Shampapi, Ndiyona, 18 January 2020.

52 Interview with R. Kanguro, Kehemu, 18 January 2020.

53 Interview with G.N. Weka, Rucara, 29 July 2009.

54 Caley, 'A Study of Vakwangali Traditional Clothing'.

55 Interview with P. Namwere, Kehemu, 18 January 2020.

56 Similarly, in South Africa, some Indian male migrants left their wives in the households of their brothers or fathers during their absence. See U. Dhupelia-Mesthrie, 'Split-Households: Indian Wives, Cape Town Husbands and Immigration Laws, 1900s to 1940s', South African Historical Journal, 66, 4 (2014), pp. 635-55.

57 See, for example, NAN NAO 93 File 42/2: Magistrate Grootfontein to Native Commissioner, Ondangwa, 'Complaint by Imelia Kandi against Leonard Juuso' - 27 January 1949. 
will you [as a wife] be allowed to open his bag? No ways! Sometimes you ... will be invited and then he [the returning contract labourer] will call on his father or mother's family to open the bag and distribute the blankets ... It was a cultural practice in the past that when a woman was married she was taken away from her parents' home and a husband placed her in the in-laws' homestead. That is where he will leave you every time he engaged into contract labour. It was in the homes of our in-laws where we experienced what we saw as our own version of [Djwaini] Johannesburg Mines. ${ }^{58}$

The above experience from Kavango is similar to those of Basotho women who lived in their in-laws' homestead, where they were obliged to observe rules of respect and avoidance (hlonepho) and faced potential conflicts over the distribution of the husbands' remittances. ${ }^{59}$ Some interviewees believed that it was justified that the in-laws took charge of a returning husband's goods in order to guarantee that their son or brother did not bring magic that could harm or kill his wife. It was therefore a family precaution to avoid possible injury or death of a wife, as Bernhard Shampapi explains:

... sometimes they used to do it in that way as a means to act as witness to all items that a contract labourer brought along from work. There were some contract labourers who brought along witchcraft medicine. Others brought along medicine for fist fight. Yes, when the parents opened the bag they inspected to ensure that he did not bring along medicine that will harm his wife. If they found any bad medicine, then they invited a traditional healer to cleanse the man and burn the medicines. Some contract labourers who did not receive the cleansing became mad after their arrival from contract work. ${ }^{60}$

Seemingly, although sisters and mothers gained the right to distribute a contract labourer's wealth and estate ${ }^{61}$ in the absence of a male figure, the control and safe-keeping of such material items still remained in the hands of any other male figure (such as a surviving maternal uncle), as the case below attests:

I am now leaving the metal box of goods to our elderly sister Sofia, to whom we are now looking up like our own mother ... Those loincloths inside and the buckets and plates which I brought from contract work should be shared amongst you and your younger siblings. Then she [Sofia] asked 'where is that metal box of goods, where did you keep it?' He said 'it is kept for safety at your uncle Shamuyambiri'. ${ }^{62}$

Women, especially mothers, used delaying tactics to keep sons at home longer. For example, they convinced their sons not to return to contract labour until they had settled the issue of marriage. Tuhemwe Shevekwa narrated from his personal experience:

I stayed there in Tjaisa $^{63}$ only for one day. The next day I said 'oh, no, mummy I am leaving'. Then my mother tried to stop me and said I must wait first to meet the woman they have proposed for me. I told her I cannot wait and I gave them all the presents I bought for the girl and her family. But after further convincing I agreed to stay a little bit longer for my mother to go and bring the girl I was destined to marry. ${ }^{64}$

58 Interview with R. Kanguro, Kehemu, 18 January 2020.

59 Bonner, 'Desirable or Undesirable Basotho women?', p. 239.

60 Interview with B.L. Shampapi, Ndiyona, 18 January 2020.

61 For more on estate distribution of contract labourers in Namibia, see Namhila, 'Record Keeping and Missing "Native Estate" Records'.

62 Interview with V. Mbandje, Katere, 2008.

63 For more on Portuguese control in 'Tjaisa' (Portuguese-controlled settlements), see I. Brinkman, 'Town, Village and Bush: War and Cultural Landscapes in South-Eastern Angola (1966-2002)', Africa Focus, 25, 2 (2012), p. 35.

64 Interview with F.T. Shevekwa, Sharuwanda, 30 July 2009. 
The contract labour system sometimes resulted in conjugal breakdown, as some women remarried or got pregnant during their husband's absence. Similarly, a husband could decide to settle permanently and remarry at work destinations, as the following example indicates:

I want to please inform woman X of Omashaka area that her husband who is in the police zone has divorced her and that he is now married to a woman of this territory. She must therefore look for another man. Kindly write to me after you have informed her about this. ${ }^{65}$

Women were unhappy that they had scant communication with their husbands and sons during their absence from home. Sometimes men overstayed on contract work without sending family support. Women thus requested police assistance to trace and return such men. The archives consist of written complaints from women about men who overstayed and never sent financial support and from women who requested their visits. ${ }^{66}$ The following letter from 1949 indicates this:

... a mother states that her son $\mathrm{X}$ who is in the employ of SA railways at Mariental went to the police zone to work there during 1933, and that he has never visited her since. Mother now requests that $\mathrm{X}$ be persuaded to come and visit her, as she is getting old, and would like to see him again before she dies. ${ }^{67}$

The above statements indicate that women faced loneliness and emotional distress while husbands and sons were on contract labour. The experiences of women from Kavango are similar to that of Basotho women, who were described as lonely, helpless and in poverty as a result of the contract labour system. ${ }^{68}$

When workers stayed in the Police Zone, they caused disruption to the local 'buy-in' to the contract labour system. The colonial authorities also worried about whether chiefs would agree to keep sending workers. Although communities and chiefs in Kavango could agree to send their young men to work in the Police Zone, they did not want simply to send emigrants. Community members in collaboration with the colonial authorities had to deal with the problem of an mbwiti. The word mbwiti or oombwiti was used by Kavango and Ovambo people, respectively, to denote a labourer who stayed longer than usual and in some cases married in the African locations and settled permanently in the Police Zone with no intention of returning 'home'. It was the policy of the colonial administration, however, that the contract labour system should not lead to 'detribalisation' of Ovambo and Kavango men, and the influx control laws aimed to ensure that contract labourers returned 'home' after the contract labour period expired. Colonial officials were always wary of 'detribalised natives', including contract labourers, who moved to town and married local women and thus broke down the 'pure' ethnic labels upon which apartheid would eventually rely. Proclamation No. 29 of 1935 dealt with the control of the so-called 'Extra-Territorial' and 'Northern Natives', who included Angolan, Zambian, Ovambo and Kavango contract labourers. Under this proclamation, all contract labourers had to be repatriated upon expiry of their contracts, and the police on patrol had to ensure that all contract labourers produced their unexpired employment permits or passes. Those contract labourers who tried to settle permanently

65 NAN NAO 93 file 42/2: Magistrate Lüderitz to Native Commissioner, Ondangwa, 'Complaints by Local Natives against Natives in the Police Zone' - 3 August 1953.

66 For similar cases in Ovamboland, see M. McKittrick, 'Reinventing the Family: Kinship, Marriage, and Famine in Northern Namibia, 1948-1954', Social Science History, 21, 3 (1997), pp. 265-95.

67 NAN NAO 93 file 42/2: Native Commissioner, Rundu to Magistrate, Mariental, 'Complaints by Local Natives against Natives in the Police Zone' - 19 December 1949. Contract labourers from Kavango could be sent throughout the territory. Mariental, for example, almost 1,000 kilometres south of Rundu, is a nodal point for the sheep farming sector and home a large rail yard.

68 See E. Gordon, 'Women Left Behind: A Study of the Wives of the Migrant Workers of Lesotho', International Labour Organisation Working Paper (Geneva, ILO, 1978). 
after the end of the contract faced deportation and jail. Oral narratives indicate that the colonial administration carried out some clean-up campaigns in the Police Zone to induce some oombwiti to return home. ${ }^{69}$ Circular labour migration was dependent on migrant workers being economically involved in the Police Zone while maintaining no cultural allegiance to it. The system was built on the premise that 'home' was only in the sending area, never in the work area or the Police Zone. While the majority of Kavango migrant labourers in the Police Zone retained an allegiance to Kavango as home, a sufficient number took up permanent residence in the Police Zone that the politics of 'detribalisation' was important to officials and the community.

'Detribalised' migrant workers disrupted this delicate balancing act. However, the women were the ones who suffered most when this balance was upset, leading to the migration of some women. There are indications that, in South Africa, women who had little to gain by staying at home migrated to urban areas in search of opportunities presented by economic developments in the towns and villages. In South Africa, these women did not participate in the formally organised migrant labour system. They were neither recruited by outside employers nor sent out by chiefs or homestead heads as part of a socially sanctioned or controlled process. ${ }^{70}$ In Namibia, although women from former Kavango and Ovamboland were prevented from entering urban areas without a pass or permission from chiefs and male household heads, some women, especially from Ovambo, were recruited through direct coordination between employers and colonial officials to work as servants in the Police Zone for a few months. The following case makes this clear.

\begin{abstract}
With reference to your minute no. $2 / 2$ dated the 22 nd ultimo, I beg to inform you that there is no objection to entry into Tsumeb of the Native girl in question, provided 1 . She is first medically examined and is found to be free from Venereal Diseases (VD) and 2. A written guarantee is obtained from the employer that she will repatriate the girl at any time when called upon to do so by the administration. If you are not satisfied that the guarantee is good, then please accept a cash deposit. Authority is hereby granted for native female $\mathrm{X}$ to enter the urban area of Tsumeb, for a period of two months, subject to the usual conditions, example, medical examination and return railway ticket. ${ }^{71}$
\end{abstract}

Generally, the contract labour system had positive and negative effects on women. Economically, for example, women were self-reliant on food production through agricultural activities, wild fruit collection and the hunting of small animals and birds for family sustenance during men's absence from home, as Makena Muduva pointed out:

... eeh, how about our fingers and cultivating? We used to set up traps for birds, I personally used to set up traps and used to collect the birds killed in the trap which became our food. In the past meat was easily available. Sometimes if you were lucky you would come across a dead animal which wild dogs had killed and had left some pieces behind and you picked up the remaining pieces of meat and you survived on it. ${ }^{72}$

Another woman provided a detailed assertion about women's self-reliance and hard work for family sustenance during men's absence from rural homes:

when my father used to travel to contract work, he left us with our mother, and we would herd the livestock and also do cultivation until our father returned. When my father returned,

69 Interview with Kamenye Likuwa, Kangweru, 13 August 2009.

70 Walker, 'Gender and the Development of the Migrant Labour System'.

71 See NAN NAO 093 File 42/2: Officer in Charge of Natives Affairs, Tsumeb to Officer in Charge of Native Affairs, Oshikango, 'Application by Mrs. K. Arends to Take a Native Girl to Tsumeb for a Few Months' 1 August 1940.

72 Interview with M. Muduva, Ndiyona, 2008. 
he would find containers of mahangu cereals at home. He would then ask my mother, 'is this what you cultivated and consumed with the children? Then she would answer, 'yes this was it, but we also used to collect wild fruits until at this point that you have now returned and found us. ${ }^{73}$

These are an indication that women and children collaborated to make ends meet during men's absence. Apart from the fear of contracting diseases from returning husbands, the magic or fist-fight medicine that some contract labourers brought along apparently required that they engage in sex with women other than their wives for the medicine to take effect. ${ }^{74}$ Since most women refused sexual advances from contract labourers, it is said that some men went mad and, eventually, women bore the burden of providing social support to these mentally sick men. When contract labourers returned, they underwent a cleansing process before they could be allowed to intermingle with the family. There seems a broader meaning behind the cleansing of returning contract labourers upon arrival, in the sense that they were likely to have viewed their workplaces in the Police Zone as a source of witchcraft and a danger to culture. This adds further evidence to the understanding that, in Kavango, and probably in other sending areas, there was a two-way movement of cultural processes and obligations that had to be upheld and sustained to ensure the continuity of community social relations.

Women's experiences of the contract labour system had the effect of drawing them into the liberation struggle, since contract labour, contract labourers' activism and Namibia's anti-colonial and anti-apartheid struggles became intertwined. Colonial officials' violence against men involved in contract labour and liberation politics made a strong impression on women witnesses. Theresia Shidona, who was born on the Namibian side of the Kavango river in 1915 and was married in the Limbaranda area in the late 1960s, recalled witnessing Portuguese atrocities against returning contract labourers who were accused of co-operating with the South West Africa People's Organisation (SWAPO) and the União Nacional para a Independência Total de Angola (UNITA) ${ }^{75}$ Shidona explained the fate of the returning contract labourers and their families at the hands of the Portuguese colonial officials:

they [the Portuguese officials] really killed people in Limbaranda! Some; oh my mother! There [on the Angolan side of the Kavango] they put all those returning from contract work in a queue. They put them all in queues like the way we queue up around here for old-age pension. And then the gun shots would ensue 'tau-tau-tau-tau!' They left the corpses in a heap and said: 'let us move on to the next house'. What do you think did the people do next? These ones were fleeing and so were the others $\ldots{ }^{76}$

Women's traumatic memories of such violence demonstrate an aspect of the burden that the contract labour system placed not only on migrant labourers themselves but also on their families and communities. Women themselves were politicised by their experiences of it, and they were instrumental in the political mobilisation of contract labourers. The case of SWAPO activist Nathaniel Maxuilili, who was based in the Walvis Bay area in the 1960s, is one example. He would sometimes be arrested but, during his absence, women took over his work. ${ }^{77}$ Evidence shows that some women joined the SWAPO Youth League (SYL) and

73 Interview with P. Namwere, Kehemu, 18 January 2020.

74 Ibid.

75 For discussions on co-operation between UNITA and SWAPO in the 1960s, see V.A. Shigwedha, 'The Relationship between UNITA and SWAPO: Allies and Adversaries', Journal of Southern African Studies, 40, 6 (2014), pp. 1275-87.

76 Interview with T. Shidona, Guma, 11 August 2009.

77 Interview with B.L. Shampapi, Ndiyona, 28 July 2009. 
became part of the SYL force that mobilised workers during the 1971-72 strike. ${ }^{78}$ Although Namibia received its independence in 1990, migration from the northern communal areas (predominantly the former Kavango and Ovamboland) to cities and work sites in what was once termed the Police Zone continues to this day. Further investigations into the changes since 1972 must be undertaken to understand the extent of these continuities and transformations.

\section{Conclusion}

This article has analysed the social and cultural dynamics in the labour sending area of the Kavango. It asserts that colonialism and contract labour depended upon and transformed existing pre-colonial local cultural frameworks, such as 'the people's child' and the observance of taboos, in the context of a locally defined understanding of 'home'. It further shows that the contract labour system depended upon maintaining a balance of sending area observances and the very real necessity of the contract labourer keeping a sense of the Kavango as 'home', which became exceedingly difficult to uphold. Furthermore, the article explores views of the burden placed by the contract labour system on women, specifically in terms of the colonial and patriarchal control over women's mobility from 'home' and women's coping strategies to overcome these burdens.

Labour mobility from Kavango after Namibia's independence is no longer restricted to men. The community and family expectation that a woman should observe taboo acts as a safety precaution for the sake of a travelling husband no longer rests on women only but now seems an equal expectation of both genders. Further research should explore the changing meaning and locality of home and their effects on marriages and family relationships in independent Namibia.

\section{Acknowledgements}

Some of the information in this article is based on a section on 'women in labour narratives' in my $2012 \mathrm{PhD}$ thesis, eventually published as a monograph in 2020 by the Basler Afrika Bibliographien, Switzerland. ${ }^{79} \mathrm{I}$ am grateful to the Carl Schlettwein Foundation, all the interviewees and all friends and colleagues for their immeasurable support in the completion of this article.

KLetus Muhena Likuwa

Senior Researcher, Multidisciplinary Research Centre, University of Namibia, PO Box 99547, 340 Mandume Ndemufavo Avenue, Windhoek, Namibia.E-mail: klikuwa@unam.na

78 Chicago Committee for African Liberation, This Is the Time: Interview with Two Namibian Women (Chicago, CCAL, 1977), pp. 15-16.

79 Likuwa, Voices from the Kavango. 